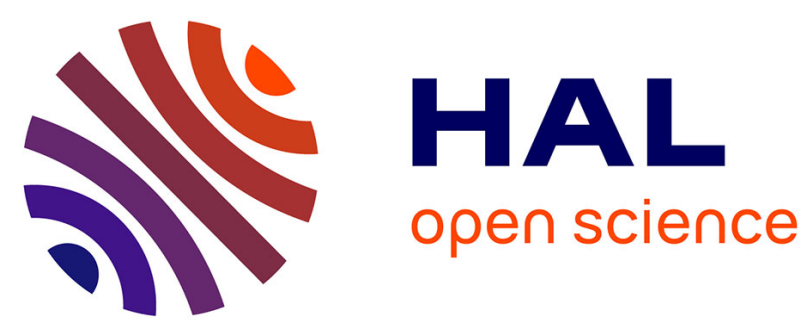

\title{
Potentially toxic element fractionation in technosoils using two sequential extraction schemes
}

Bashar Qasim, Mikael Motelica-Heino

\section{To cite this version:}

Bashar Qasim, Mikael Motelica-Heino. Potentially toxic element fractionation in technosoils using two sequential extraction schemes. Environmental Science and Pollution Research, 2014, 21 (7), pp.50545065. 10.1007/s11356-013-2457-4 . insu-00925086

\section{HAL Id: insu-00925086 \\ https://hal-insu.archives-ouvertes.fr/insu-00925086}

Submitted on 3 Mar 2014

HAL is a multi-disciplinary open access archive for the deposit and dissemination of scientific research documents, whether they are published or not. The documents may come from teaching and research institutions in France or abroad, or from public or private research centers.
L'archive ouverte pluridisciplinaire HAL, est destinée au dépôt et à la diffusion de documents scientifiques de niveau recherche, publiés ou non, émanant des établissements d'enseignement et de recherche français ou étrangers, des laboratoires publics ou privés. 


\title{
(Published in Environmental Science and Pollution Research)
}

\section{Potentially toxic element fractionation in technosoils using two sequential extraction schemes}

\author{
Bashar Qasim $^{1,2, *}$. Mikael Motelica-Heino ${ }^{1}$ \\ ${ }^{1}$ CNRS/ISTO Institut des Sciences de la Terre d'Orléans, UMR-CNRS 7327 Campus \\ Géosciences, Université d'Orléans, 1A rue de la Férollerie, 41071 Orléans, France. \\ ${ }^{2}$ School of Applied Sciences, University of Technology, Baghdad, Iraq.
}

\begin{abstract}
This study reports the chemical fractionation of several potentially toxic elements ( $\mathrm{Zn}$, $\mathrm{Pb}, \mathrm{Cd}, \mathrm{As}$, and $\mathrm{Sb}$ ) in contaminated technosoils of two former smelting and mining areas using two sequential extraction schemes. The extraction schemes used in this study were the Tessier's scheme and a modified BCR scheme. The fractions were rearranged into four equivalent fractions defined as acid soluble, reducible, oxidizable, and residual to compare the results obtained from two sequential extraction schemes. Surface soils were samples from a waste landfill contaminated with $\mathrm{Zn}, \mathrm{Pb}$, and $\mathrm{Cd}$ located at Mortagne-duNord (MDN; North France) and from a settling basin contaminated with PTE such as As, $\mathrm{Pb}$, and $\mathrm{Sb}$ located at La Petite Faye (LPF; Limoges, France). The study of the $\mathrm{Zn}, \mathrm{Pb}$, $\mathrm{Cd}$, $\mathrm{As}$, and $\mathrm{Sb}$ partitioning in the acid soluble, reducible, oxidizable, and residual fractions of the technosoils revealed that $\mathrm{Zn}, \mathrm{Cd}$, and $\mathrm{Pb}$ were mainly associated with the acid soluble and reducible fractions for MDN site, while $\mathrm{As}, \mathrm{Sb}$, and $\mathrm{Pb}$ were associated with residual fraction for LPF site. Fractionation results indicate that the percentages of $\mathrm{Zn}, \mathrm{Pb}, \mathrm{Cd}, \mathrm{As}$, and $\mathrm{Sb}$ extracted in $\mathrm{Fe}-\mathrm{Mn}$ oxide bound fraction of Tessier's scheme were always higher than those extracted by modified BCR scheme. This may be attributed to the stronger Tessier's scheme conditions used to extract this fraction. In contrast the percentages of $\mathrm{Zn}, \mathrm{Pb}, \mathrm{Cd}$, $\mathrm{As}$, and $\mathrm{Sb}$ extracted in the organic fraction of the modified BCR scheme were always higher than those of the Tessier's scheme. The order of mobility of PTE was as follows: $\mathrm{Cd}>\mathrm{Zn}>\mathrm{Pb}$ in $\mathrm{MDN}$ site and $\mathrm{As}>\mathrm{Sb}>\mathrm{Pb}$ in $\mathrm{LPF}$ site. PTE were distributed in all soil fractions, with the most relevant enrichments in extractable and residual fractions. A significant amount of $\mathrm{Cd}, \mathrm{Pb}$, and $\mathrm{Zn}$ were rather mobile, which suggests that these elements can be readily available to plants and soil organisms.
\end{abstract}


Keywords: Potentially toxic element fractionation, Sequential extraction, Mining and smelting activities, contaminated technosoils

\section{Introduction}

Mining and smelting activities are considered as highly polluting sources of potentially toxic elements (PTEs) in the environment (Shu et al. 2001; Schuwirth et al. 2007). In fact both mining and smelting processes produce large amounts of wastes resulting in soil contamination (Davies 1983; Adriano 2001). These processes introduce PTE into the environment through gaseous and particulate emissions but also liquid and solid wastes (Dudka and Adriano 1997). The exposure of the population to these PTE involves a risk to human health by consuming the plants grown on the contaminated sites (Nabulo et al. 2010).

Since the determination of the total concentration of PTE in soils does not give sufficient information about the mobility and toxicity of these elements (Nowak 1995; Szulczewski et al. 1997; Rauret 1998; Petit and Rucandio 1999), additional information on the concentrations of particular physicochemical forms of the PTE is in fact required as their behavior in the environmental system depends on their chemical speciation (Merian and Clarkson 1991; Rodriguez et al. 2009). Speciation can be defined as the identification and quantification process of different species or binding forms in which an element occurs (Ure et al. 1995; Ure and Davidson 2001). PTE in soils are partitioned between the different phases present, i.e., organic matter, oxyhydroxides of iron, aluminum and manganese carbonates, sulfides, clays, etc., and are retained on these solid phases by different mechanisms, i.e., ion exchange, complexation, precipitation or co-precipitation (Weber 1991; Benedetti et al. 1995), or are retained in the lattice of soil minerals. Since the behavior of PTE in the soil-water-plant system depends on their speciation, the determination of PTE partition in soils assessed by sequential extraction schemes can give useful information. Different extraction schemes have been widely used to mimic differing environmental conditions, with strong acids being used to determine the total concentration of PTE and weaker solutions to determine compounds that are relatively soluble and bioavailable (Anju and Banerjee 2010).

The main goal of sequential extraction is to convert PTE bound in the different solid phases into soluble forms with a specific chemical extractants used at each step (Tokalioglu et al. 2000a, b). In these sequential extraction schemes, a series of progressively harsher reagents is used to dissolve increasingly refractory forms of these 
elements, from the more mobile to the more refractory (MacLaren and Crawford 1973; Shuman 1985).

However, sequential extraction schemes are greatly influenced by experimental factors such as the choice of chemical reagents, specific extraction time, and weight ratio of sample to volume of the extraction solution. Thus, there are many criticisms of these schemes as several operationally defined artifacts may occur including the lack of specificity of reagents, the possibility of re-adsorption of released PTE to the remaining fractions (Belzille et al. 1989; Hass and Fine 2010) and the potential alteration of other phases during one extraction step (Li and Thornton 2001).

The best-known sequential extraction scheme (Tessier et al. 1979) consists of five steps in which PTTE are considered to be distributed among different soil fractions:(1) exchangeable, (2) bound to carbonate, (3) bound to Fe-Mn oxides, (4) bound to organic matter, and (5) residual. Many sequential extraction schemes derived from the Tessier one have been applied to soils and sediments to fractionate PTE by using different chemical extractants to obtain useful information about the bioavailability and mobility of these elements (Elliott et al. 1990; Krishnamurti et al. 1995) in particular, one of the Community Bureau of Reference (BCR) (Ure et al.1993) which is similar to that produced by Tessier et al. with the main difference in the first extraction step of the scheme.

The aims of this work was thus to: (1) investigate the chemical fractionation of PTE, respectively $\mathrm{Zn}, \mathrm{Pb}$, and $\mathrm{Cd}$, in contaminated surface technosoils from a former smelting site (Mortagne-du-Nord (MDN), France) and $\mathrm{As}, \mathrm{Pb}$, and $\mathrm{Sb}$ from a former mining site (La Petite Faye (LPF), Limoges, France), and (2) compare the efficiency and suitability of two sequential extraction schemes (Tessier and a modified BCR) for these soils.

\section{Materials and methods}

\subsection{Soil sampling}

Two sites were selected for this study. The first one is metallophyte grassland located in Mortagne-du-Nord (MDN) in Northen France. Thus area has been occupied for over 60 years by a $\mathrm{Zn}$ smelter unit linked to a sulfuric acid production unit and a $\mathrm{Pb}$ smelting unit for a few years. The site has been back-filled with slags and smelting crucible to a thickness of about 3 meters. More than 30 metal-bearing ( $\mathrm{Zn}, \mathrm{Pb}$ and $\mathrm{Cd}$ ) mineral species have been identified such as sulfides, sulfates, carbonates, oxides and silicates (Thiry and van Oort 1999). The second site is the former mine tailing of La Petite Faye (LPF) located $60 \mathrm{~km}$ North-East of 
Limoges (France), where mining wastes have been stored in a settling basin from 46 years ago. The main PTE present in soils are As, Pb and Sb (Néel et al. 2003; Nénert et al. 1997).

Three distinct locations (zone1, zone2 and zone3) from each site were selected according to the level of PTE concentrations and spatial distribution of the vegetation cover. One $\mathrm{kg}$ of surface soil $(0-20 \mathrm{~cm})$ was sampled at each location with a stainless steel spade. In the MDN site the vegetation cover consists of essentially Arabidopses hallari and Avena sativa L. whereas, in LPF site, Graminea, Equisetum telmateia, Betula pendula and Pteridium aquilinum were present with large horsetails of black alder and poplar (Dutreuil et al. 1997).

All soil samples collected were carefully transferred to clean polyethylene bags before transport to the laboratory. Collected soil samples were oven-dried at a constant temperature of $40^{\circ} \mathrm{C}$, manually homogenized and then quartered. Two equivalent fractions were obtained from each quartered sample. One fraction was used for the determination of the soil physicochemical properties whereas the other fraction was used for chemical analysis of PTE. Samples for chemical analysis were sieved first using a $2 \mathrm{~mm}$ mesh sieve, to remove gross plant matter and subsequently crushed to pass through a $250 \mu \mathrm{m}$ sieve (Brooks 1983).

\subsection{Reagents and standards}

All the reagents used to prepare the extracting solutions were products of analytical-grade quality (Merck pro-analysis, Darmstadt, Germany). All solutions and dilutions were prepared using doubly deionized water $\left(18.2{\mathrm{M} \Omega \mathrm{cm}^{-1}}^{-}\right.$) (Thermo Scientific Barnstead Easy pure II systems). Standard stock solutions of $1000 \mathrm{mg} . \mathrm{l}^{-1}$ of different elements were prepared from metal wires or salts of purity higher than 99.998\% (VWR international, BDH Prolabo ICP Standards, Belgium). Diluted standard working solutions were prepared from these on a daily basis. All laboratory glassware and plastic ware were rinsed three times with double deionized water after being soaked in a $\mathrm{HNO}_{3}(10 \%$, v/v) bath for $24 \mathrm{~h}$.

\subsection{Analysis of the soil physico-chemical properties}

Physico-chemical properties of the samples $(<2 \mathrm{~mm}$ fraction) were characterized by routine soil testing laboratories according to standardized French (AFNOR 1999) or international (ISO 1999) procedures (Table 3). $\mathrm{pH}$ and EC of each samples were determined in distilled water extracts (1:2.5 w/v) (NF ISO 10390 (2005)). Total organic carbon concentrations were determined according to ISO (1999). Cation exchange capacity (CEC) was determined by the $0.05 \mathrm{~N}$ cobalthexamine method (Aran et al. 2008). Organic matter was determined according to (Storer 1984) procedure depends on loss of weight on ignition (LOI).

\subsection{X-ray fluorescence spectrometer (XRF)}


The total concentration of PTE in the contaminated soil samples was determined from X-ray fluorescence using a XMET 5100 X-ray spectrophotometer (Oxford Instruments Analytical GmbH, Germany). PTE in the soil were determined by XRF method by pressed soil pellets with an acquisition delay time of $3 \mathrm{~min}$. for each sample.

\subsection{Soil mineralogical characterization}

Powder X-ray diffraction was used for mineralogical characterization in bulk studied soils using a diffractometer INEL XRM3000 montage transmission (geometry Debye-Scherrer), $(\mathrm{CoK} \alpha, 40 \mathrm{kV}, 30 \mathrm{~mA})$ between 5 to $90^{\circ} 2 \theta$. The analyses of minerals were carried out on thin section of the bulk sample using INEL diffractometer equipped with an INEL CPS 120 detector (Debye-Scherrer geometry).

\subsection{Sequential extractions}

Sequential extraction schemes of Tessier et al. (1979) and of the European Union's Standards, Measurements and Testing Program (SM\&T) (Sahuquillo et al. 1999) were used in this study and are summarized in (Table1 and Table 2) respectively. Each extraction step was performed in triplicate, starting with $1 \mathrm{~g}$ of original soil material. The aqua regia step performed on the residue from step 4 for (Tessier's scheme) or step 3 for (BCR scheme) was based on the ISO 11466 method (ISO norm 11466 (1995).

Metal concentrations in all extracts from these sequential extraction schemes were determined by ICP-MS (Finnigan Element XR, Thermo Electron, Germany). Additionally blanks of the different extractants were analyzed in triplicate and further subtracted from the soil samples. The accuracy of the sequential chemical extraction scheme was determined by comparing the sum of the concentrations obtained at the different steps of the extraction scheme with total metal content (Cuong and Obbard 2006). 
Table 1: Extraction conditions of the Tessier's scheme

\begin{tabular}{|c|c|}
\hline Fraction & Extractants and conditions \\
\hline Exchangeable & $1 \mathrm{M} \mathrm{MgCl}_{2}(\mathrm{pH}=7), 20 \mathrm{ml}, 1 \mathrm{~h}$ \\
\hline $\begin{array}{l}\text { Bound to } \\
\text { carbonate }\end{array}$ & $1 \mathrm{M} \mathrm{NaOAc}(\mathrm{pH}=5), 20 \mathrm{ml}, 1 \mathrm{~h}$. \\
\hline Reducible & $0.04 \mathrm{M} \mathrm{NH}_{2} \mathrm{OH} \mathrm{HCl}, 20 \mathrm{ml}, 95^{\circ} \mathrm{C}, 6 \mathrm{~h}$. \\
\hline Oxidizable & $\begin{array}{l}15 \mathrm{ml} 30 \% \mathrm{H}_{2} \mathrm{O}_{2} \text { and } 3 \mathrm{ml} 0.02 \mathrm{M} \mathrm{HNO}_{3}, 2 \mathrm{~h}, 85^{\circ} \mathrm{C} \text {, } \\
3.2 \mathrm{M} \mathrm{NH}_{4} \mathrm{OAc}, 5 \mathrm{ml}, 85^{\circ} \mathrm{C}, 3 \mathrm{~h} \text {. }\end{array}$ \\
\hline Residual & $\mathrm{HF}, \mathrm{HClO}_{4}, \mathrm{HNO}_{3}$ \\
\hline
\end{tabular}

Table 2: Extraction conditions of the modified BCR scheme

\begin{tabular}{|l|l|}
\hline \multicolumn{1}{|c|}{ Fraction } & \multicolumn{1}{|c|}{ Extractants and conditions } \\
\hline Exchangeable & $0.11 \mathrm{M} \mathrm{CH}_{3} \mathrm{COOH}, 40 \mathrm{ml}, 16 \mathrm{~h}$ \\
\hline Reducible & $0.1 \mathrm{M} \mathrm{NH}_{2} \mathrm{OH} \mathrm{HCl}(\mathrm{pH}=2), 40 \mathrm{ml}, 16 \mathrm{~h}$ \\
\hline Oxidizable & $8.8 \mathrm{M} \mathrm{H}_{2} \mathrm{O}_{2}, 10 \mathrm{ml}, 85 \mathrm{C}, 1 \mathrm{~h}$ and $8.8 \mathrm{M} \mathrm{H}_{2} \mathrm{O}_{2}, 10 \mathrm{ml}$, heated to \\
\hline dryness, and $1 \mathrm{M} \mathrm{NH} \mathrm{H}_{4} \mathrm{OAc},(\mathrm{pH}=2), 50 \mathrm{ml}_{1}, 16 \mathrm{~h}$
\end{tabular}




\section{Results and discussion}

\subsection{Physico-chemical properties of the studied soils}

The main physico- chemical properties of the soil samples are summarized in (Table3). The $\mathrm{pH}$ of MDN soils was slightly acid and ranged from 6.14 to 6.92, while the $\mathrm{pH}$ of LPF soils was acidic to slightly acid and ranged from 3.65 to 5.75 , this could be because of the acid forming process occurring during mine tailing weathering producing acid mine drainage leading to the increase in hydrogen ion activity. Organic matter ranged from 8.26 to $13.84 \%$ and from 5.27 to $6.83 \%$ for MDN and LPF respectively. Organic carbon of both MDN and LPF ranged from 3.35 to $6.45 \%$ and 0.3 to $1.67 \%$ respectively. Total PTE concentrations for MDN site ( $n=3)$ were as follows: $\mathrm{Zn}\left(3111-7721 \mathrm{mg} \mathrm{kg}^{-1}\right), \mathrm{Pb}\left(879-3558 \mathrm{mgkg}^{-1}\right)$ and $\mathrm{Cd}$ $\left(53-72 \mathrm{mgkg}^{-1}\right)$, while, total PTE concentrations for LPF site $(n=3)$ were as follows: As $\left(2677\right.$ - $\left.83937 \mathrm{mgkg}^{-1}\right), \mathrm{Pb}\left(362\right.$ - $\left.16100 \mathrm{mgkg}^{-1}\right)$ and $\mathrm{Sb}\left(100-871 \mathrm{mgkg}^{-1}\right)$. The concentrations of $\mathrm{Zn}$, As and $\mathrm{Pb}$ are greater than: (i) the possible toxicity values $(10-300,5-$ 20 and 30-300 mg/kg, respectively; (Kabata-Pendias 2001; Kiekens 1995; McGarth and Loveland 1992) and (ii) the normal background levels given (e.g. $1-50 \mathrm{mgkg}^{-1}$ for $\mathrm{Zn}, 1-30$ $\mathrm{mgkg}^{-1}$ for As and $9-50 \mathrm{mgkg}^{-1}$ for $\mathrm{Pb}$ (Wilson et al. 2010) for soils of diverse origins and lithologies throughout the world.

\subsection{Soil mineralogical composition}

As derived from the XRD analysis, there is no significant differences in mineralogical composition between the different soil samples are found for the LPF site. Surface soils in the studied former mining area are mainly constituted by silicate species such as quartz, muscovite, clinoclore, feldspar together with clay minerals such as illite, kaolinite and chlorite. The MDN surface soils are mainly constituted by quartz, muscovite, albite, dolomite, orthoclase and calisite.

\subsection{Fractionation of the PTE}

Results of the PTE fractionation in the studied soils for the different zones for the two sequential extraction schemes are shown in (Fig.1and Fig.2). The contents of these elements extracted in each steps of sequential extractions scheme are summarized in (Tables 4 and 5). In the Tessier' scheme the equivalent fraction used were T1 (Exchangeable fraction), T2 (Bound to carbonate), T3 (reducible (Fe-Mn oxide bound) fraction), T4 (oxidisable (organic/sulphide) fraction) and T5 (residual fraction). Whereas, in modified BCR scheme, the equivalent fraction used were B1 (acid soluble (carbonate bound) equivalent to (T1+T2)), 
B2 (reducible (Fe-Mn oxide bound) fraction equivalent to T3), B3 (oxidizable (organic/sulphide) fraction), equivalent to T4) and B4 (residual fraction, equivalent to T5).

Table 3: Physicochemical characteristics of the soils and PTE total concentrations of the selected zones from Mortagne-du-Nord (MDN) and La Petite Faye (LPF)

\begin{tabular}{|c|c|c|c|c|c|c|c|c|}
\hline Zone & pH & EC & ОМ\% & TOC\% & CEC & Zn & $\mathbf{P b}$ & Cd \\
\hline & & $(\mu \mathrm{s} \mathrm{cm})$ & & & $($ cmol kg ) & \multicolumn{3}{|c|}{$\left(\mathrm{mg} \mathrm{kg}^{-1}\right)$} \\
\hline MDN1 & 6.92 & 112 & 8.26 & 3.35 & 7.2 & 7721 & 3558 & 72 \\
\hline MDN2 & 6.35 & 112 & 10.28 & 4.39 & 8.5 & 3111 & 876 & 63 \\
\hline \multirow[t]{2}{*}{ MDN3 } & 6.14 & 113 & 13.84 & 6.45 & 6.7 & 3124 & 879 & 53 \\
\hline & & & & & & As & $\mathbf{P b}$ & $\mathbf{S b}$ \\
\hline LPF1 & 3.65 & 258 & 6.46 & 0.3 & 18.3 & 83937 & 16100 & 871 \\
\hline LPF2 & 4.93 & 200 & 5.27 & 0.47 & 39.7 & 37458 & 8536 & 498 \\
\hline LPF3 & 5.75 & 150 & 6.83 & 1.67 & 29.1 & 2677 & 362 & 100 \\
\hline $\begin{array}{l}E C \text { elec } \\
\text { exchan }\end{array}$ & cal c & ductivity, & organ & & total org & & & \\
\hline
\end{tabular}




\subsubsection{MDN site}

\section{Zinc}

Tessier's extraction scheme showed that $\mathrm{Zn}$ recovery was between $95.7 \%$ and $98.4 \%$ for all studied samples which can be regarded as acceptable in comparison with other studies (Hongyu Liu 2005; Rodriguez 2009). Zn was mainly associated with carbonate fraction and accounted for $38.2 \%, 31.1 \%$ and $30.3 \%$ of total $\mathrm{Zn}$ for zones1, 2 and 3 respectively (Fig.1a). The concentration of $\mathrm{Zn}$ in reducible fraction ranged from 25.8 to $28.3 \%$ of total $\mathrm{Zn}$ for all three zones. On average, the concentration of $\mathrm{Zn}$ in exchangeable fraction accounted for 17$21.7 \%$ and in residual fraction $14.3-17.2 \%$ for all studied zones. Data in (Fig.1a) indicate that general distribution of $\mathrm{Zn}$ into the various fractions for all studied zones followed the order: $\mathrm{T} 2>\mathrm{T} 3>\mathrm{T} 1>\mathrm{T} 5>\mathrm{T} 4$. This observation is in agreement with that of Pardo et al. 1990.

BCR extraction scheme showed that Zinc recovery was ranged between $96.1 \%$ and $99.7 \%$ for all studied samples. $\mathrm{Zn}$ distribution pattern in each fraction followed the order: B1 $>$ B2 $>$ B4 $>$ B3 (Fig.2a). About 53.4\%, 42.2\% and 48.8\% of total $\mathrm{Zn}$ occurs in soluble fraction (B1) for zone1, 2 and zone 3 respectively. $21.2-26.1 \%$ is distributed in reducible fraction, $18-20 \%$ is incorporated into silicate lattice, while fraction of $\mathrm{Zn}$ bound to oxidisable fraction represents less than $11 \%$ of total $\mathrm{Zn}$ for all studied samples. The first extraction step (B1) is important for this metal. A possible explanation for this is the presence of calcareous minerals, which act as a strong adsorbent for $\mathrm{Zn}$ in mine tailings (Anju 2010; Nannoni et al. 2011).

Collectively, both extraction schemes gave similar results for $\mathrm{Zn}$. In fact the relative $\mathrm{Zn}$ associations, as provided by both extraction schemes are similar for all four equivalent fractions (i.e. acid soluble > reducible > residual > organic/sulphide bound) for all studied zones. $\mathrm{Zn}$ fractionation is dominated by acid soluble fraction. However it was observed that the amount of $\mathrm{Zn}$ extracted in acid soluble fraction by BCR scheme was higher than Tessier's scheme, as more Zn was extracted in (B2) by BCR scheme than by Tessier's scheme (T3).

\section{Lead}

Lead recovery in Tessier's extraction scheme ranged between $92 \%$ and $110 \%$ for all studied samples. The relative distribution of $\mathrm{Pb}$ among different fractions in zone1 followed the order: $\mathrm{T} 2 \approx \mathrm{T} 3>\mathrm{T} 4>\mathrm{T} 5>\mathrm{T} 1$ (Fig. 1b). It can be seen that $\mathrm{Pb}$ was mainly associated with carbonate and reducible fractions accounting for $31.4 \%$ and $30.8 \%$ respectively of total $\mathrm{Pb}$ content. $\mathrm{Pb}$ in zone1 is shown to be strongly associated with carbonate fraction. This is coherent with thermodynamic prediction (Brookins 1988) that cerrusite $\left(\mathrm{PbCO}_{3}\right)$ would be the dominant lead mineral at the Eh- $\mathrm{pH}$ conditions of mine tailing. Additionally $\mathrm{CaCO}_{3}$ may act as a strong 
adsorbent for $\mathrm{Pb}$ and could complex $\mathrm{Pb}$ as $\left(\mathrm{PbCO}_{3}\right)$ ( $\mathrm{Li}$ and Thornton 2001). The next $\mathrm{Pb}$ fractions were oxidisable and residual which represents $<18 \%$ and $<15 \%$ respectively.

The fractionation pattern of $\mathrm{Pb}$ in both zone 2 and zone 3 was: T3>T2>T4>T5>T1 (Fig.1b). This was comparable for the two zones, demonstrating that Fe-Mn oxide bound fraction (42.9\%) for zone 2 and (32.8\%) for zone 3 is the predominant fraction. Fe-Mn oxides are in fact important scavengers of metals in soils particularly at a high $\mathrm{pH}$ range $(\mathrm{pH}>7.0)$ (Tipping et al. 1986). The remaining $\mathrm{Pb}$ content was distributed among carbonate, oxidisable and residual fractions represents $<29 \%,<13 \%$ and $<10$ for zone 2 and $<21 \%,<26 \%$ and $<13 \%$ for zone 3 respectively.

BCR extraction scheme showed a percentage recovery for $\mathrm{Pb}$ ranging between $97 \%$ and $113 \%$ for all studied samples. $\mathrm{Pb}$ association in zone1 followed the order: $\mathrm{B} 1>\mathrm{B} 2>\mathrm{B} 3>\mathrm{B} 4$ (Fig.2b), indicating that highest percentages of $\mathrm{Pb}$ were associated with acid soluble (32.6\%), Fe-Mn oxide bound (28.9\%), organic/sulphide (27.2\%) and residual fraction (11\%). In contrast $\mathrm{Pb}$ distribution among different fractions in zone2 and zone3 followed the order: $\mathrm{B} 2>\mathrm{B} 3>\mathrm{B} 1>\mathrm{B} 4$, indicating the relative importance of Fe-Mn oxide bound $(33.7 \%$ and $30.6 \%)$ and organic/sulphide fraction (31.1\% and 30.1\%) for both zone 2 and 3 respectively. This finding is in agreement with that of Ramos et al. 1994; Romaguera et al. 2008; Zemberyova et al. 2006.

Fractionation results obtained for $\mathrm{Pb}$ from the two extraction schemes were also similar for all studied zones. The relative distribution of $\mathrm{Pb}$ in all four fractions was also similar. The most abundant fractions were acid soluble and Fe-Mn oxide bound. Again, a higher amount of $\mathrm{Pb}$ was extracted with reducible fraction by Tessier's extraction scheme compared to BCR scheme. In contrast for organic/sulphide bound fractions it was the opposite.

\section{Cadmium}

Cd recovery in Tessier's extraction scheme was ranged between $84 \%$ and $105 \%$ for all studied samples. The fractionation of $\mathrm{Cd}$ in each fraction followed the order: $\mathrm{T} 1>\mathrm{T} 5>\mathrm{T} 3>\mathrm{T} 2>\mathrm{T} 4$ (Fig.1c) for zone1 and 2, while it followed the order: T1 $>\mathrm{T} 2>\mathrm{T} 3>\mathrm{T} 4>\mathrm{T} 5$ for zone 3, matching the usual distribution of this element in contaminated soils (Narwal et al. 1999; Sanchez et al. 1999; Kaasalainen and Yli-Halla 2003). Soil Cd was mainly associated with exchangeable fraction representing about $46.1 \%, 46.1 \%$ and $37.64 \%$ of total Cd for zones 1, 2 and 3 respectively. This fraction includes $\mathrm{Cd}$ held by electrostatic adsorption and specifically adsorbed. This fraction may be also called easily soluble and/or exchangeable. This form of Cd is considered more mobile and phytoavailable (Dudka and Chlopecka 1990). It can be seen that for the non- exchangeable fraction, the highest percentage of $\mathrm{Cd} 22.3 \%$ and $23.9 \%$ in zone 1 and 2 was associated with residual fraction followed by Fe-Mn oxide bound, 
carbonate bound and organic/sulphide fractions whereas, in zone3, the fractionation pattern revealed that $\mathrm{Cd}$ was most abundant in carbonate bound fraction and at least in organic/sulphide bound fraction.

Cd recovery in BCR extraction scheme was ranged between $93 \%$ and $110 \%$ for all studied samples. Cd fractionation for both zones1 and 2 decreased in the order: $\mathrm{B} 1>\mathrm{B} 4>\mathrm{B} 2>\mathrm{B} 3$ (Fig.2c). It can be further seen that for the majority of samples analyzed, $\mathrm{Cd}$ is distributed between acid soluble $53.5 \%$ and $45.8 \%$, residual $16.8 \%$ and $31.6 \%$, Fe-Mn oxide bound $15 \%$ and $17 \%$ and organic/sulphide $14 \%$ and $5.4 \%$ fraction for zones1 and 2 respectively. $\mathrm{Cd}$ distribution in zone3 was followed the order: B1 $>$ B2 $>$ B3 $>$ B4 (Fig.2c), indicating the relative importance of the acid soluble fraction followed by the Fe-Mn oxide bound, organic/sulphide and residual fractions.

The relative $\mathrm{Cd}$ associations, as revealed by both extraction schemes, are similar in all four equivalent fractions for all studied samples indicating the suitability and comparability of both methods for $\mathrm{Cd}$. The fractionation is dominated by acid soluble fraction. It was also observed that more $\mathrm{Cd}$ was extracted in reducible (Fe-Mn oxide bound) fraction by Tessier's extraction scheme than by BCR scheme in B2. Again, more Cd was extracted in organic fraction (B3) by BCR scheme than by Tessier's scheme. However, for both methods $\mathrm{Cd}$ is extracted maximally in the most mobile phases. 
$\mathbf{a}$

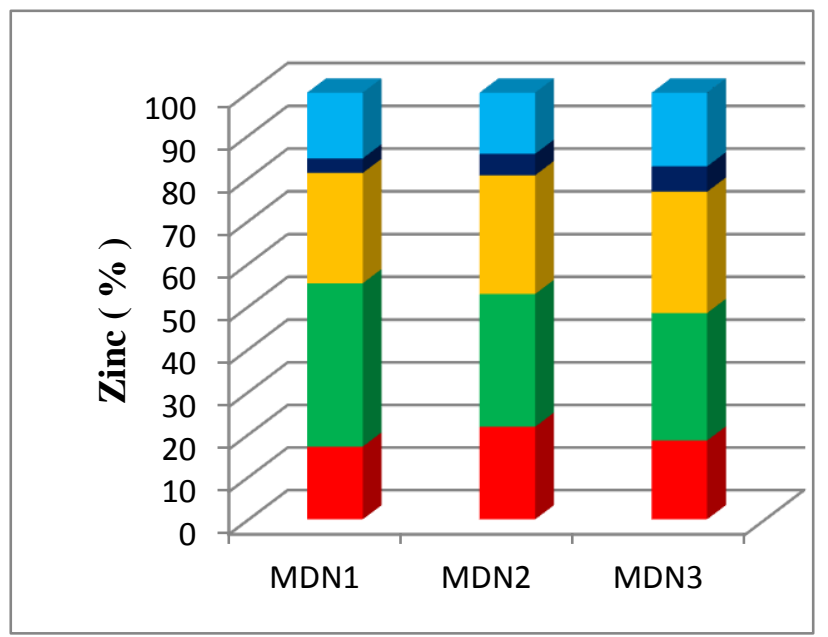

b

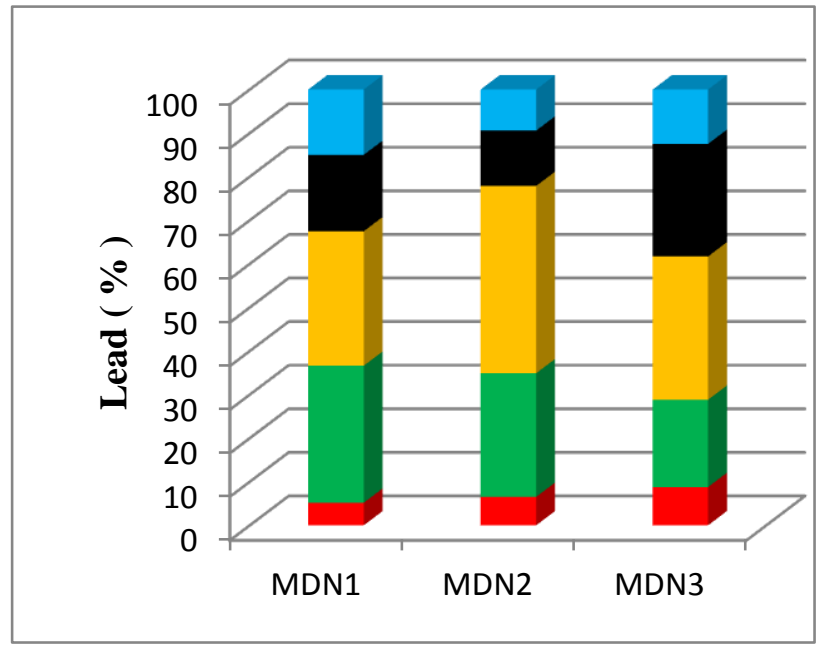

c

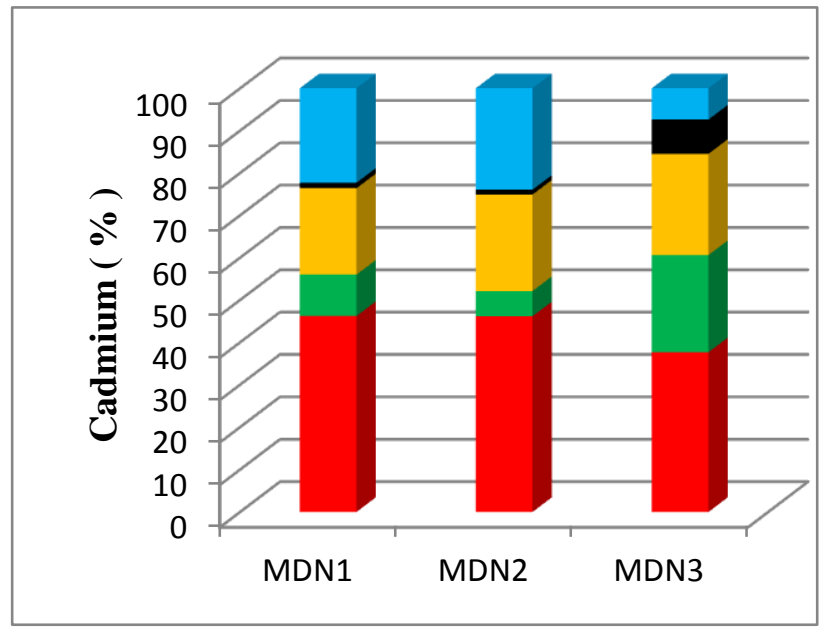

d

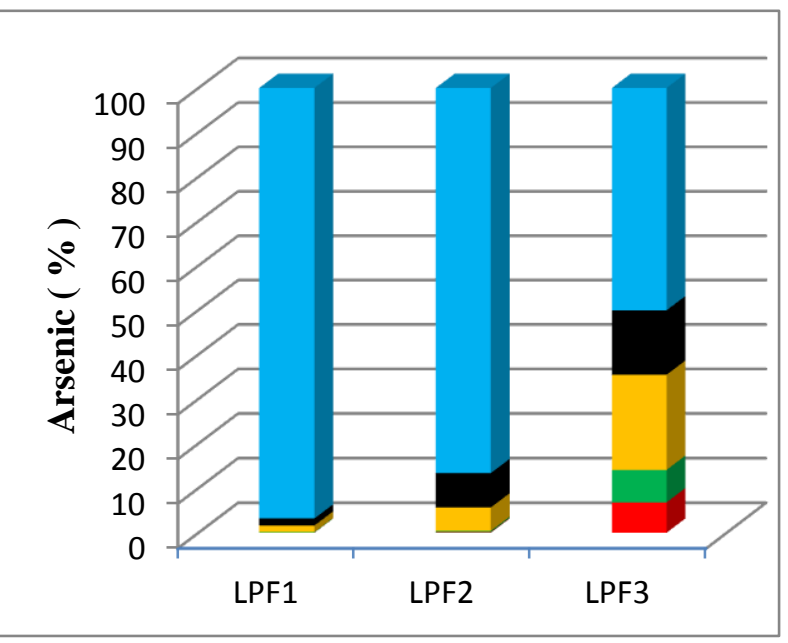

e

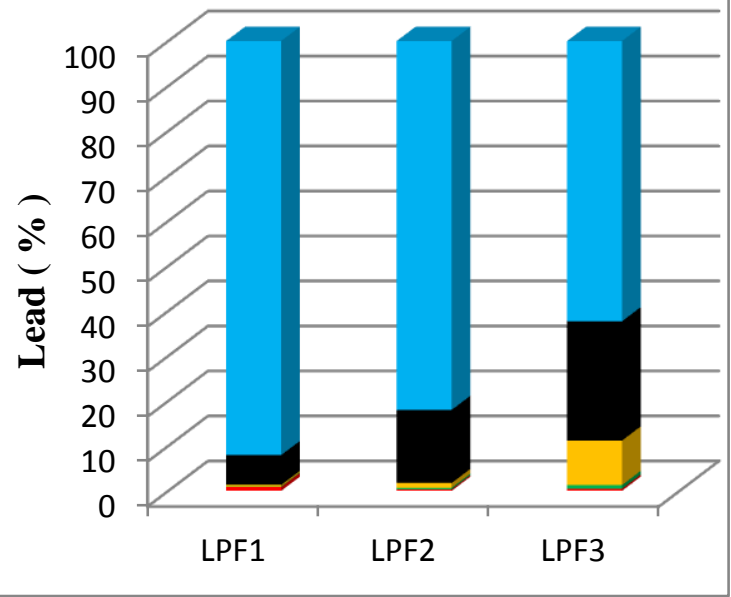

$\mathbf{f}$

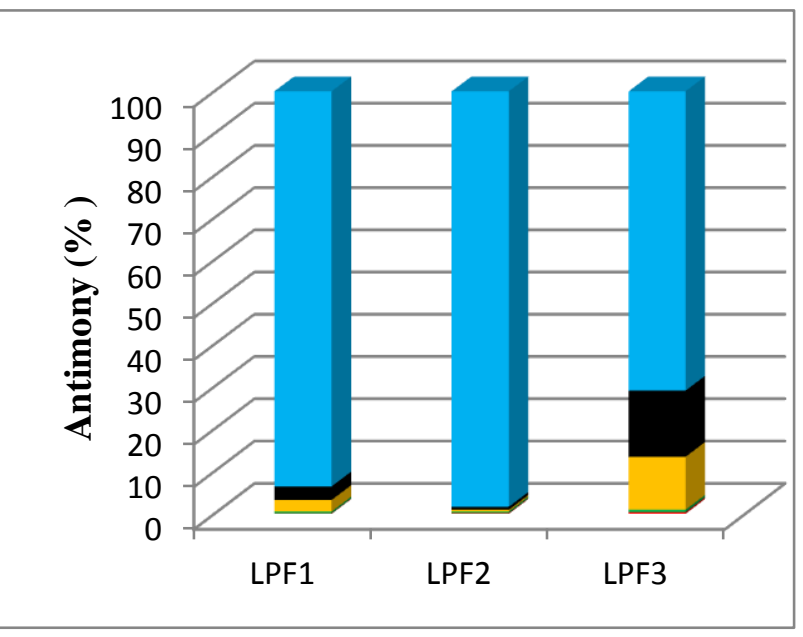

T1

\begin{tabular}{ll|l|l} 
T2 & T3 \\
$\square$
\end{tabular}

Fig.1: Chemical distribution of $\mathrm{Zn}(\mathrm{a}), \mathrm{Pb}$ (b and e), $\mathrm{Cd}(\mathrm{c}), \mathrm{As}(\mathrm{d}), \mathrm{Sb}$ (f) in the different soil fractions in MDN and LPF (Tessier's scheme): T1 (exchangeable), T2 (carbonates), T3 (reducible), T4 (oxidizable), T5 (residual). 
$\mathbf{a}$

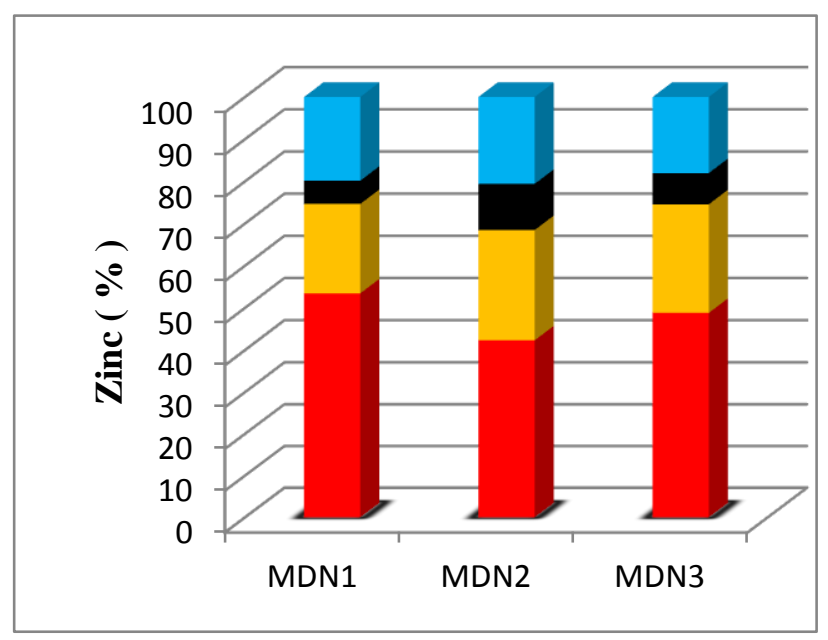

b

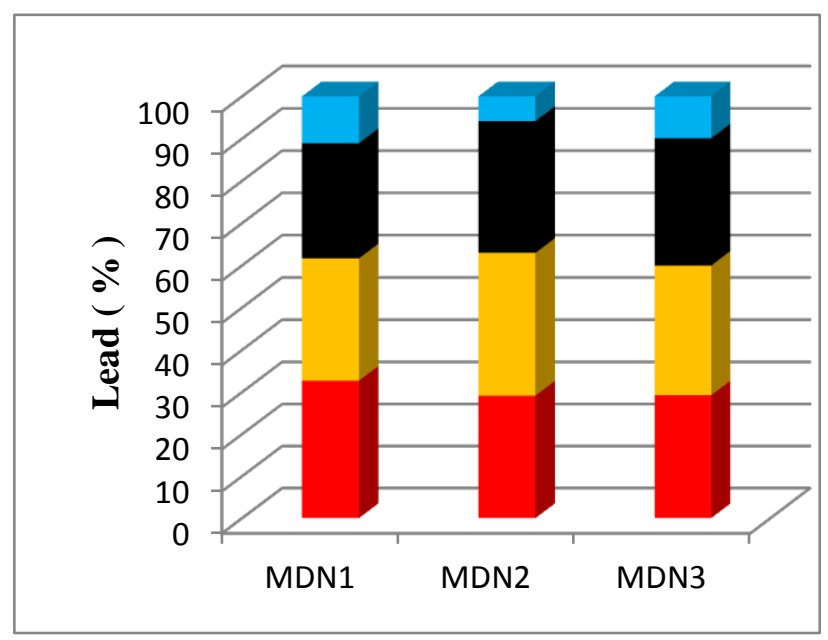

c

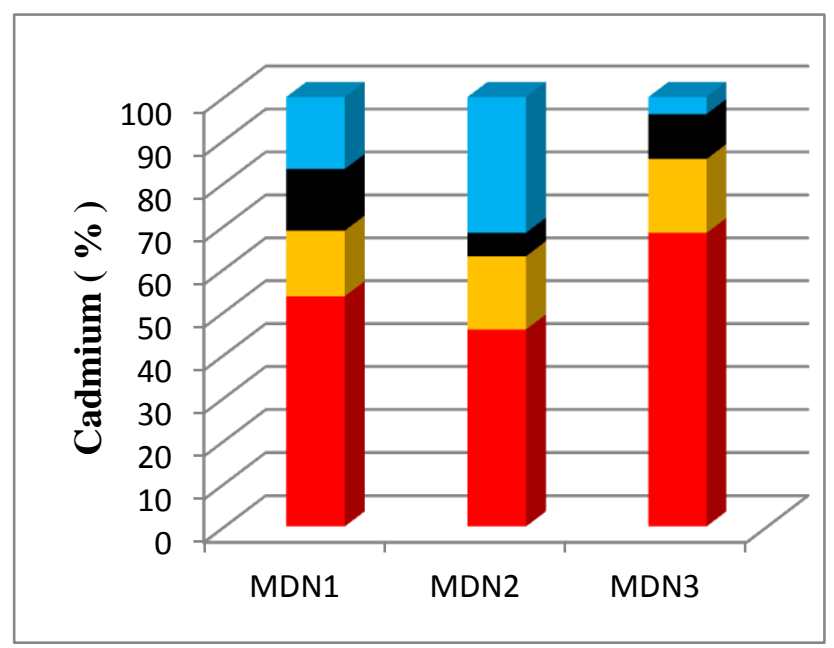

d

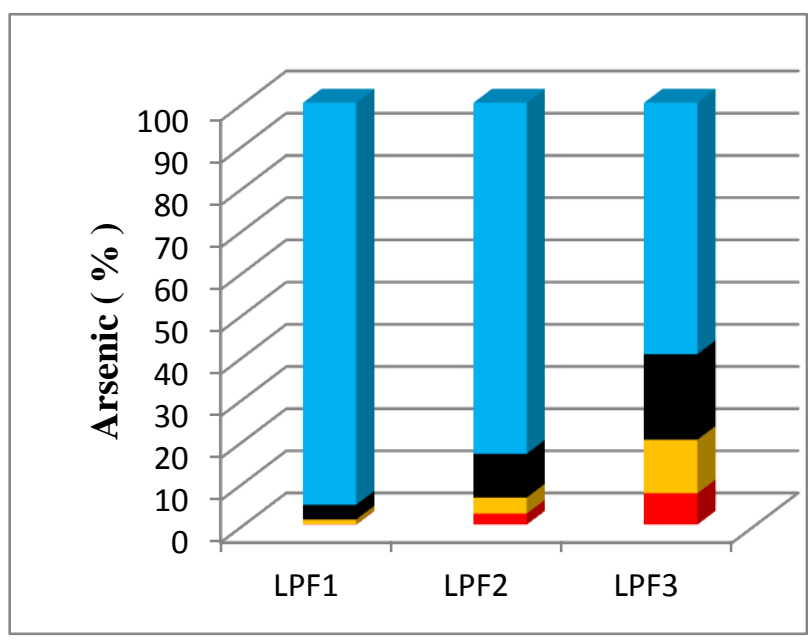

e

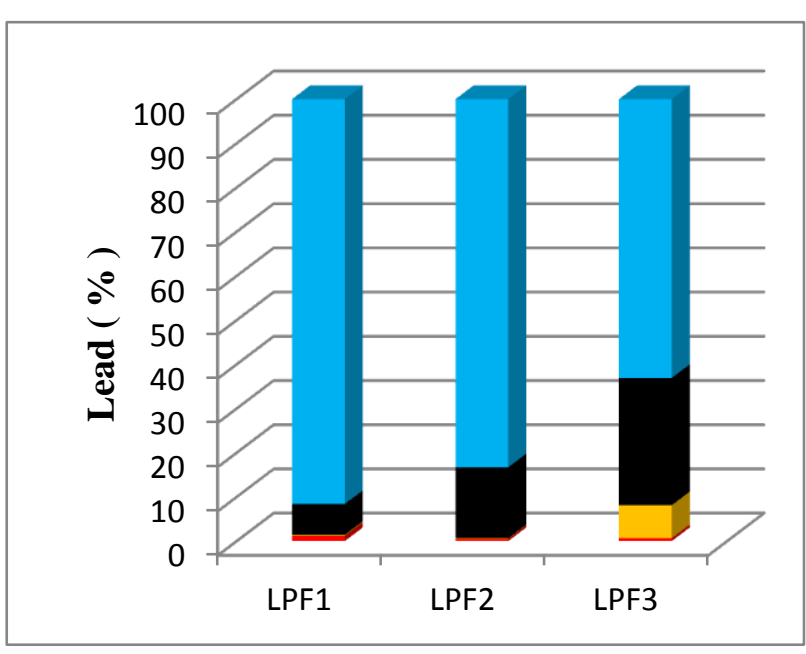

f

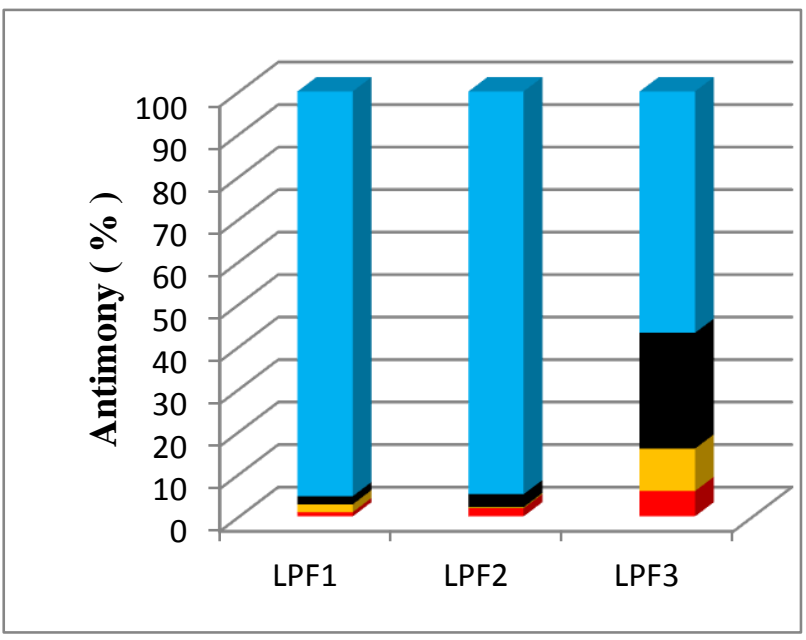

B1 $\quad$ B2 $\square$ B3 $\quad$ B4

Fig.2: Chemical distribution of $\mathrm{Zn}(\mathrm{a}), \mathrm{Pb}$ (b and e), $\mathrm{Cd}$ (c), $\mathrm{As}(\mathrm{d}), \mathrm{Sb}$ (f) in the different soil fractions in MDN and LPF (modified BCR scheme): B1 (acid soluble), B2 (reducible), B3 (oxidizable), B4 (residual). 
Table 4: Potentially toxic element fractionation in the different solid phases as obtained from the Tessier'sscheme ${ }^{\mathrm{a}}$.

$\begin{array}{lcccccc}\text { Zone } & \begin{array}{c}\text { Exchangeable } \\ \text { (T1) }\end{array} & \begin{array}{c}\text { Carbonate } \\ (\mathrm{T} 2)\end{array} & \begin{array}{c}\text { Reducible } \\ (\mathrm{T} 3)\end{array} & \begin{array}{c}\text { Oxidizable } \\ (\mathrm{T} 4)\end{array} & \begin{array}{c}\text { Residual } \\ (\mathrm{T} 5)\end{array} & \% \text { Recovery } \\ \mathbf{M D N 1} & & & & & & \\ \mathrm{Zn} & 17.12 & 38.28 & 25.8 & 3.42 & 15.36 & 95.77 \\ \mathrm{~Pb} & 5.19 & 31.43 & 30.86 & 17.54 & 14.97 & 96.8 \\ \mathrm{Cd} & 46.19 & 9.78 & 20.41 & 1.3 & 22.3 & 84.55\end{array}$

\section{MDN2}

$\mathrm{Zn}$

21.77

31.11

27.78

5.01

14.31

97.73

$\mathrm{Pb}$

6.52

28.37

42.97

12.7

9.41

110.25

$\mathrm{Cd}$

46.13

5.95

22.79

1.13

23.96

86.83

\section{MDN3}

$\mathrm{Zn}$

$$
18.53
$$

29.91

28.36

5.92

17.25

98.41

$\mathrm{Pb}$

8.8

20.01

32.89

25.82

12.46

92.4

22.95

8.1

7.36

105.43

\section{LPF1}

$\begin{array}{lllllll}\mathrm{As} & 0.01 & 0.09 & 1.49 & 1.57 & 96.82 & 99.51 \\ \mathrm{Sb} & 0.09 & 0.42 & 2.72 & 3.21 & 93.53 & 91.93 \\ \mathrm{~Pb} & 0.83 & 0.09 & 0.39 & 6.62 & 92.05 & 98.33\end{array}$

\section{LPF2}

As

0.11

0.28

5.26

7.69

86.63

99.27

$\mathrm{Sb}$

0.16

0.37

0.41

0.7

98.33

90.14

$\mathrm{Pb}$

0.32

0.35

1.05

16.25

82

92

\section{LPF3}

$\begin{array}{lllllll}\mathrm{As} & 6.81 & 7.27 & 21.32 & 14.51 & 50.07 & 97.07 \\ \mathrm{Sb} & 0.36 & 0.58 & 12.48 & 15.62 & 70.94 & 88.47 \\ \mathrm{~Pb} & 0.45 & 0.83 & 9.89 & 26.5 & 62.31 & 87.46\end{array}$

${ }^{\mathrm{a}}$ All values are in percentages. 
Table 5: Potentially toxic element fractionation in the different solid phases as obtained from the modified BCR scheme ${ }^{\mathrm{b}}$.

$\begin{array}{lccccc}\text { Zone } & \begin{array}{c}\text { Acid soluble } \\ (\mathrm{B} 1)\end{array} & \begin{array}{c}\text { Reducible } \\ (\mathrm{B} 2)\end{array} & \begin{array}{c}\text { Oxidizable } \\ (\mathrm{B} 3)\end{array} & \begin{array}{c}\text { Residual } \\ (\mathrm{B} 4)\end{array} & \% \text { Recovery } \\ \mathbf{M} & & & & & \\ \mathrm{ZnN1} & 53.44 & 21.2 & 5.51 & 19.48 & 95.77 \\ \mathrm{~Pb} & 32.69 & 28.94 & 27.27 & 11.08 & 105.1 \\ \mathrm{Cd} & 53.56 & 15.28 & 14.34 & 16.8 & 93.44\end{array}$

\section{MDN2}

$\mathrm{Zn}$

42.29

$\mathrm{Pb}$

$\mathrm{Cd}$

MDN3

$\mathrm{Zn}$

$\mathrm{Pb}$

$\mathrm{Cd}$

48.80

29.22

68.31

0.11

1.11

1.84

0.22

$\mathrm{Pb}$

1.19

3.8

0.27

0.13

0.51

$\mathrm{Pb}$

2.62

1.9

12.72

20.29

27.24

28.79

\section{LPF3}

95.27

99.7

1.91

95.26

93.72

6.97

91.61

94.92

$\begin{array}{llllll}\mathrm{As} & 7.43 & 12.72 & 20.29 & 59.54 & 93.89 \\ \mathrm{Sb} & 5.96 & 9.97 & 27.24 & 56.8 & 90.75 \\ \mathrm{~Pb} & 0.65 & 7.45 & 28.79 & 63.08 & 91.49\end{array}$

${ }^{\mathrm{b}}$ All values are in percentages. 


\subsubsection{LPF site}

\section{Arsenic}

Tessier's extraction scheme exhibits As recovery ranged between 97\% and 99\% for all studied samples. Data obtained during the sequential extraction steps carried out on soil samples of LPF site indicate that As was distributed in the order: T5> $>$ T4 $>\mathrm{T} 3>\mathrm{T} 2>\mathrm{T} 1$ (Fig.1d) for all three zones. Results showed that in zone1 more than $90 \%$ of As was distributed in residual fraction, while, in zone 2 and 3 it represents more than $80 \%$ and $50 \%$ respectively of total As content. The majority of As remained from residual fraction was distributed among other different fractions. The sum of As extracted in fractions T1, T2, T3 and fraction T4 was almost negligible for zone1 and 2 samples, whereas, in zone 3, Fe-Mn oxide and organic/sulphide fractions represent $21.3 \%$ and $14.5 \%$ respectively.

As recovery by BCR extraction scheme ranged between $93 \%$ and $99 \%$ for all studied samples. More than $90 \%$ of total As was bound to residual fraction in zone1, while both zone 2 and 3 represents $80 \%$ and $60 \%$ respectively of total As content. The other fractions showed a lower As content, especially for B1and B2 which showed less than $1 \%$ of total As content. In contrast zone 3 presents 7.4 and $12.7 \%$ for B1 and B2 respectively. As was concentrated in residual fractions (Fig.2d), which in term of mobility may be considered immobile. The important quantities of As in residual fraction were in agreement with results of other studies investigating the distribution of this element in contaminated soils (Fernandez et al. 2004; Novoa-Munoz et al. 2007; Pueyo et al. 2008). The distribution of As into soil fractions $\mathrm{B} 4>\mathrm{B} 3>\mathrm{B} 2>\mathrm{B} 1$ did not change significantly as a function of contamination level; nevertheless, the anthropogenic input mainly affected residual and reducible fractions.

It can be seen that fractionation results obtained from the two methods were similar (Table 2), the most abundant fraction being the residual fraction. Despite of the highest As contents leached from residual fraction, it can be seen that percentage of As extracted by Tessier's scheme for reducible fraction is little higher than that of BCR scheme, while As extracted in oxidisable fraction of BCR scheme was higher than that extracted in Tessier's T4 (oxidisable) fraction.

\section{Antimony}

In Tessier's extraction scheme, Sb recovery ranged between $88 \%$ and $91 \%$ for all studied samples. Sb was largely distributed in residual fraction accounting for $93.5 \%, 98 \%$ and $70.9 \%$ for zones1, 2 and zone 3 respectively. Results showed that highest percentage of Sb was associated with residual fraction which represents metal bound to crystalline phase, followed by oxidisable fraction which represents metal bound to organic/sulphide fraction with a 
percentage of $(0.7-15.6 \%)$ for each three zones. Sb amount relate to other fractions was very low and represents less than $3 \%$ for all zones. In all three zones, the distribution of Sb into various fractions was as follows: $\mathrm{T} 5>>\mathrm{T} 4>\mathrm{T} 3>\mathrm{T} 2 \approx \mathrm{T} 1$ (Fig.1f).

BCR extraction results showed a suitable Sb recovery ranged between $90 \%$ and $96 \%$ for all studied samples. More than $90 \%$ of total $\mathrm{Sb}$ was found to be bound with refractory minerals in residual fraction in zone1and 2, while zone3, represented only $57 \%$ of total $\mathrm{Sb}$ content. $\mathrm{Sb}$ distribution followed the order: B4 $>>$ B3 $>$ B2 $>$ B1 (Fig.2f). This finding is in agreement with that of Alvarez-Ayuso et al. 2012; Nannoni et al. 2011, which they found that more than $90 \%$ of $\mathrm{Sb}$ was partitioned in residual fraction in former mining sites. In non- residual fraction, the highest percentage of $\mathrm{Sb}(27.2 \%)$ in zone 3 was associated with organic /sulphide fraction (B3), while in zones1 and zone 2 it represents less than $2 \%$ and $1 \%$ respectively. Reducible fraction represents less than $10 \%$ in zone 3 and less than $2 \%$ in zones 1 and zone 2.

It can be seen that a uniform fractionation pattern (residual $>$ organic $>$ oxidisable $>$ reducible $>$ exchangeable) was observed for $\mathrm{Sb}$ by both extraction schemes. The most abundant fraction was residual bound; amount of $\mathrm{Sb}$ extracted in reducible fraction by Tessier's method was in general higher than that by BCR scheme. However, more Sb was extracted in B3 fraction than in T4 (oxidisable) fraction.

\section{Lead}

$\mathrm{Pb}$ recovery in Tessier's scheme was ranged between $87 \%$ and $98 \%$ for all studied samples. It was apparent from the preliminary Tessier's sequential extraction procedure that most of $\mathrm{Pb}$ was mainly associated with residual fraction accounting more than $90 \%$ of total $\mathrm{Pb}$ content in zone1, while it represents $82 \%$ and $62 \%$ for zones 2 and 3 respectively. Pb distribution in both oxidisable and reducible fractions was variable for all zones accounted 6.26 to $26.5 \%$ for oxidisable fraction and 0.39 to $9.89 \%$ for reducible fraction in all zones. The low amount of $\mathrm{Pb}$ was associated with $\mathrm{T} 1$ and $\mathrm{T} 2$ fraction representing less than $1 \%$ for all zones. Despite the variability in total concentrations, $\mathrm{Pb}$ in all zones showed a similar distribution into various fractions: $\mathrm{T} 5>\mathrm{T} 4>\mathrm{T} 3>\mathrm{T} 2>\mathrm{T} 1$ (Fig.1e). The high percentage of $\mathrm{Pb}$ in residual fraction is in broad agreement with that observed by Paulo et al. (2011) in soil contaminated by mining activity. The input of $\mathrm{Pb}$ in contaminated soils was redistributed among various soil fractions, with highest enrichment in residual and reducible fractions.

BCR extraction scheme exhibits $\mathrm{Pb}$ recovery ranged between $91 \%$ and $98 \%$ for all studied samples. The relative distribution of $\mathrm{Pb}$ in different soil fractions followed the order: $\mathrm{B} 4>>\mathrm{B} 3>\mathrm{B} 2>\mathrm{B} 1$ (Fig.2e). This fractionation pattern revealed that $\mathrm{Pb}$ was most abundant in residual fraction showing a comparable percentage with that of Tessier's scheme. The amount of $\mathrm{Pb}$ distributed in oxidisable fraction was ranged between 6.9 to $28.7 \%$, while, it represents 
0.22 to $7.45 \%$ in reducible fraction for all zones. $\mathrm{T} 1$ and $\mathrm{T} 2$ also showed lowest $\mathrm{Pb}$ percentages $<1 \%$. $\mathrm{Pb}$ partitioning indicates that this element is rather stable, since it is mainly associated with residual fraction.

It can be seen that the distribution of this metal among different equivalent fractions is similar for the two methods. Also, the extracted amounts of $\mathrm{Pb}$ in the two schemes are slightly comparable. $\mathrm{Pb}$ content in oxidisable fraction extracted by BCR scheme was slightly higher than those of Tessier's scheme. Despite the analogous pattern in all fractions, fractionation by both extraction schemes substantiate that acid soluble bound fraction is the least abundant for all zones.

\subsection{Potential mobility of PTE in the technosoils}

The knowledge of the mobility and bioavailability of PTE depends not only upon the total concentration but also upon the chemical form of the PTE. In fact little information is provided by the total soil concentration. For instance of more soluble metal compounds are more mobile and toxic (Kwon et al. 2001). On the other hand, the first extraction steps in any sequential extraction procedure represent the most mobile and bioavailable fractions and may provide useful information about the PTE.

The order of mobility of PTE considering their abundance in different soil fractions followed the order: exchangeable $>$ bound to carbonate $>$ bound to Fe-Mn oxide $>$ bound to organic matter $>$ residual fraction (Tessier et al. 1979). Exchangeable elements are a measurement of those elements which are released most readily into environment under acidic conditions and may be considered the most dangerous fraction to environment (Stone and Marsalek 1996). Changes in ionic composition, influencing adsorption-desorption reactions or lowering of $\mathrm{pH}$ could cause remobilization of these PTE from this fraction (Ure 2001; Marin et al. 1997; Sutherland 2000). PTE bound to Fe-Mn oxides that would be released under reducing conditions represent the reducible fraction. These oxides are well known "sinks" in the surface environment for these elements (Baruah et al. 1996b) and are thermodynamically unstable under anoxic conditions (Tokalioglu 2000). PTE bound to organic matter / sulphides would be released under oxidizing conditions and thus represent the oxidisable fraction. PTE associated with oxidisable phases are assumed to remain in the soil for a longer period but may be mobilized by decomposition processes (Kennedy et al. 1997). Residual fraction represents the elements that have the strongest association with crystalline structures of the minerals and are therefore the most difficult to mobilize.

The determination of PTE mobility in soils is based on the relative amount of the metal in exchangeable fraction (T1) containing the mobile forms and in carbonate bound fraction (T2) 
containing easily mobilisable phases. The mobility index of PTE was calculated as the mobility factor (MF) based on the following equation by (Kabala and Singh 2001; Narwal et al. 1999; Salbu et al. 1998):

$M F=\frac{\left(T_{1}+T_{2}\right)}{\left(T_{1}+T_{2}+T_{3}+T_{4}+T_{5}\right)} \times 100$

Consequently, the mobility factor value determines the relative mobility and biological availability of PTE in the soil. On this basis high mobility factor (MF) values have been reported or interpreted as evidence of relatively high reactivity, high lability and high biological availability of PTE in soil (Karczewska 1996; Ma and Rao 1997).

On the basis of the MF values, the average mobility of PTE in the studied soil samples is shown graphically in Fig.3 and 4 to help compare the MF values of PTE in each studied sites. On average, the potential mobility of Cd was $52.89 \%$ for MDN studied samples. Cd can be considered the most mobile element, as about half of its total content was in exchangeable fraction. The relationship between $\mathrm{Cd}$ concentrations in exchangeable fraction and carbonate content suggest that a substantial portion of $\mathrm{Cd}$ was contained in minerals such as calcite (in which $\mathrm{Cd}$ may replace $\mathrm{Ca}$ ). As an overview of the study area, the fractionation data indicate a high mobility and bioavailability of $\mathrm{Cd}$. The results are in accordance with those obtained by Kapusta et al. 2011 and Vaněk et al. 2005, indicating that $\mathrm{Cd}$ is the most mobile of the three metals tested $(\mathrm{Cd}, \mathrm{Zn}, \mathrm{Pb})$.

The average potential mobility factor of $\mathrm{Zn}$ was $42.24 \%$. Under reducing and acidic conditions, $\mathrm{Zn}$ will easily be mobilized to the environment. Therefore compared with other PTE they were mostly abundant in the residue fraction. Thus $\mathrm{Zn}$ was more available and potentially toxic in the environment. Part of $\mathrm{Zn}$ was likely related to carbonates such as $\mathrm{Zn}$ rich calcite and/or smithsonite $\left(\mathrm{ZnCO}_{3}\right)$. Other acid-soluble minerals affecting the occurrence of $\mathrm{Zn}$ in acid soluble fraction could be sulphates $\left(\mathrm{ZnSO}_{4}\right)$ and oxide-sulphates $\left[\mathrm{ZnO} \cdot \mathrm{ZnSO}_{4}\right.$; $\mathrm{Zn}(\mathrm{OH})_{2}$. ZnSO4], whose presence was commonly detected in contaminated soils collected in mining and smelting areas (Li and Thornton 2001).

Potential mobility of $\mathrm{Pb}$ in MDN and LPF zones were $33.44 \%$ and $0.66 \%$ respectively. Change in the concentration was low because $\mathrm{Pb}$ in soil in this environment was relatively immobile. It could be noted that any change to anoxic soil conditions (e.g. caused by waterflooding) could mobilize significant amounts of adsorbed $\mathrm{Pb}$ through the destabilization of the $\mathrm{Fe}-\mathrm{Mn}$ oxyhydroxide lattices. Many researchers referred to that $\mathrm{Pb}$ in acid soluble fraction of the most contaminated soils was mainly in carbonate phases such as cerussite $\left(\mathrm{PbCO}_{3}\right)$ and 


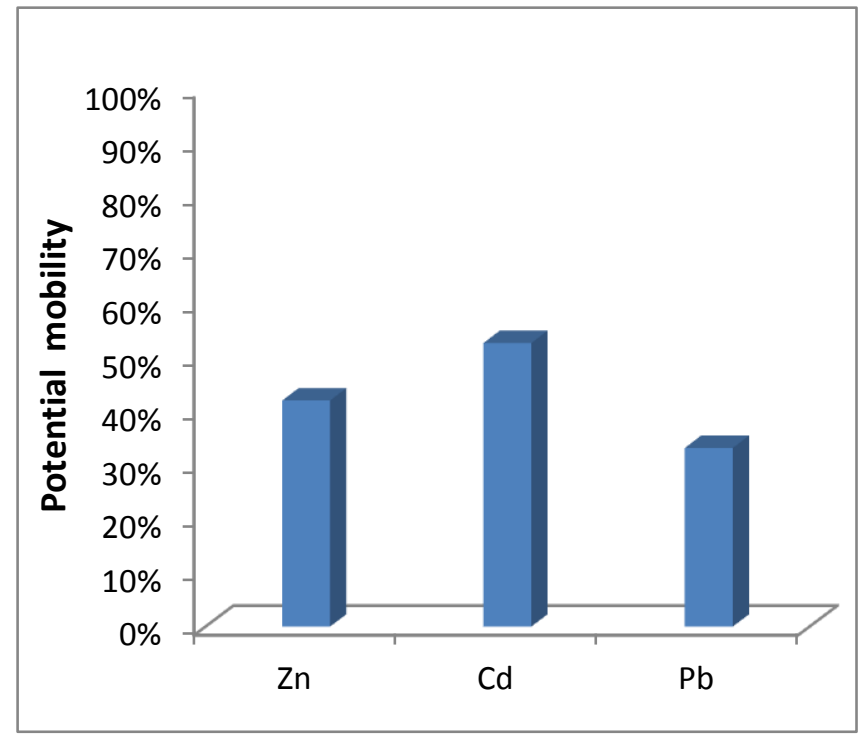

Fig.3: Potential mobility of the potentially toxic elements from the MDN site

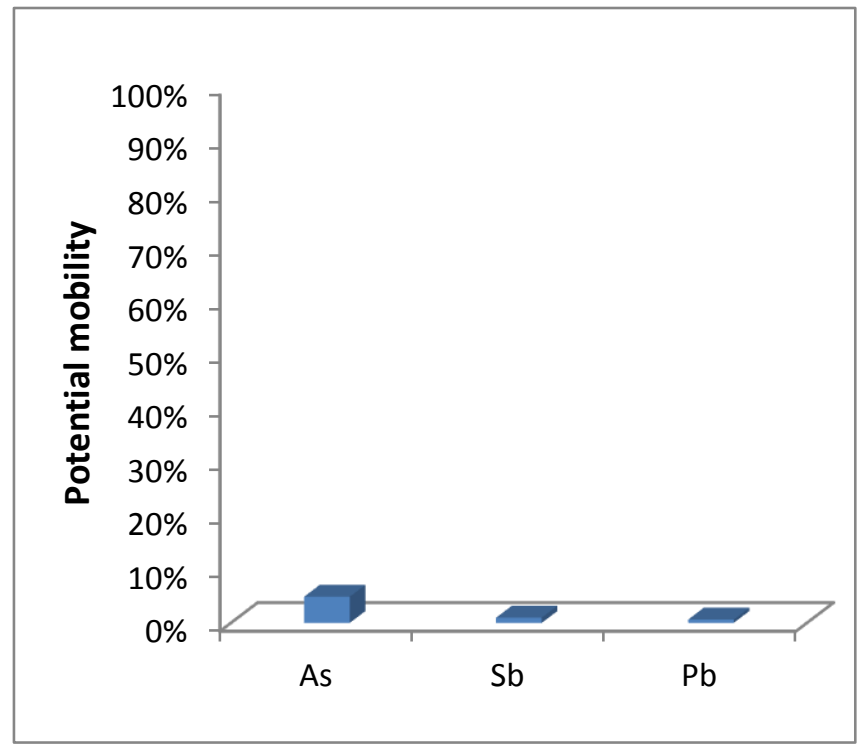

Fig.4: Potential mobility of the potentially toxic elements from the LPF site

hydrocerussite $\left[\mathrm{Pb}_{3}\left(\mathrm{CO}_{3}\right)_{2}(\mathrm{OH})_{2}\right]$ which therefore play an important role in the mobility and bioavailability of this element (Clevenger et al. 1991; Ettler et al. 2009).

The average potential mobility factor of As was $4.86 \%$. In our site, As can be considered a rather immobile element as most of this metalloid is bound to the residual mineral fraction. The chemistry of arsenic precipitation-dissolution and adsorption-desorption is complex and depends on the charge of the absorbing species and the soil surface characterization. The 
results for arsenic fractions should reflect the geochemical behavior of arsenic in the surface environment. In our study on sequential extraction of arsenic from contaminated technosoils, we found that only a very small proportion of arsenic was extracted in the early fractions compare to the total arsenic content for both extraction schemes. However, high concentrations of arsenic found in residual fractions indicate that arsenic present in these soils is difficulty released by chemical extractants from the first steps of the schemes. The important quantities of As in residual fraction were in agreement with the results of other studies investigating the distribution of this element in contaminated soils (Filippi et al. 2004; Ghosh et al. 2004; Matera et al. 2003).

Sb potential mobility factor in the LPF zones was $0.96 \%$. Similar to arsenic, Sb distribution into the soil fractions indicates that this element was rather immobile in the contaminated soils as being largely present in residual fraction. In a recent study on sequential extraction of Sb from contaminated soils, Tighe and Lockwood 2007; He 2007; Denys et al. 2008 found that a large amount (up to 90\%) of Sb was associated with the residual fraction. In general, a number of similar general trends in As and Sb fractionation in soil are evident. These include the low mobility of both $\mathrm{As}$ and $\mathrm{Sb}$ and the high proportion of both metalloids associated with the residual fraction depending on metalloid source. Metalloid associated with the crystalline and non-crystalline oxide and hydroxide minerals is often assumed to be immobile (Filella et al., 2009).

\section{Conclusion}

This study aimed to evaluate the soil fractionation of of $\mathrm{Zn}, \mathrm{Pb}, \mathrm{Cd}, \mathrm{As}$ and $\mathrm{Sb}$ in selected technosoils of two PTE contaminated sites.

The percentages of $\mathrm{Zn}, \mathrm{Pb}, \mathrm{Cd}$, $\mathrm{As}$ and $\mathrm{Sb}$ extracted in $\mathrm{Fe}-\mathrm{Mn}$ oxide bound fraction of Tessier's scheme were always higher than those extracted by modified BCR scheme. In contrast the percentages of $\mathrm{Zn}, \mathrm{Pb}, \mathrm{Cd}$, $\mathrm{As}$ and $\mathrm{Sb}$ extracted in organic fraction of modified BCR scheme were always higher than those of Tessier's scheme.

$\mathrm{Zn}, \mathrm{Pb}$ and $\mathrm{Cd}$ from $\mathrm{MDN}$ technosoils were distributed in all fractions, with greatest enrichments in acid soluble fraction in the case of $\mathrm{Cd}$. The results showed that PTE from LPF zones have the highest abundance in residual fraction. This indicates that the PTE were rather immobile. The largest proportions for $\mathrm{As}, \mathrm{Pb}$ and $\mathrm{Sb}$ were extracted in residual phase, in which PTE are strongly retained in soil minerals. This shows that the environmental risk of these PTE may be limited. However, the relatively high PTE content in LPF zones may represents some indirect environmental risk due to clay dispersion, and disaggregated soil particles bearing PTE may eventually reach and accumulate in ground waters and food chain. 
The order of mobility in technosoils was: $\mathrm{Cd}>\mathrm{Zn}>\mathrm{Pb}$ in $\mathrm{MDN}$ zones and $\mathrm{As}>\mathrm{Sb}>\mathrm{Pb}$ in $\mathrm{LPF}$ zones. The mobile and potentially bioavailable pools of these heavy elements were considerably higher in contaminated soils with respect to uncontaminated ones. In MDN zones, $\mathrm{Cd}, \mathrm{Zn}$ and $\mathrm{Pb}$ can be considered the most mobile elements and potentially available to the biosphere, representing therefore a more significant environmental risk than $\mathrm{Pb}, \mathrm{Sb}$ and As in LPF zones. The quantity of mobile and potentially bioavailable PTE in MDN soils could threaten the quality of crops, with the real risk that these elements enter the food chain. The partitioning patterns of PTE in soils of this region will therefore be a sound basis for studies focusing on soil organisms (such as earthworms), cultivated and wild vegetables and the safety of food stuffs. Comparison of both sequential extraction schemes indicates that the results are only empirically defined and are not totally exclusive to the specified mineral phase.

\section{Acknowledgements}

The authors wish to acknowledge Dr. Emmanuel Joussein (Université de Limoges) for help in soil sampling and XRF analysis, and Dr. Arnaud Gauthier (Université Lille 1) for help in soil sampling.

\section{References}

Adriano, D.C., 2001. Trace Elements in Terrestrial Environments; Biogeochemistry, Bioavailability and Risks of Metals, 2nd edn, Springer, New York, pp: 866.

Afnor (1999) Recueil de Normes Françaises. Qualité des sols, Afnor Paris.

Álvarez-Ayusoa, E., Otonesa, V., Murciegob, A., García-Sáncheza, A., Santa Reginaa, I., 2012. Antimony, arsenic and lead distribution in soils and plants of an agricultural area impacted by former mining activities. Science of The Total Environment 439, 3543.

Anju, M., Banerjee, D.K., 2010. Comparison of two sequential extraction procedures for heavy metal partitioning. Chemosphere 78, 1393-1402.

Aran, D., Maul, A., Masfaraud, J.F., 2008. A spectrophotometric measurement of soil cation exchange capacity based on cobaltihexamine chloride absorbance. C R Geoscience $340,865-871$.

Baruah, N.K., Kotoky, P., Bhattacharyya, K.G., Borah, G.C., 1996. Metal speciation in Jhanji River sediments. Science of The Total Environment 193,1-12. 
Belzille, N., Lecomte, P., Tessier, A., 1989. Testing readsorption of trace elements during partial chemical extractions of bottom sediments. Environmental Science \&Technology 23, 1015-1020.

Benedetti, M.F., Milne, C.J., Kinniburgh, D.G., van Riemsdijk, W.H., Koopal, L.K., 1995. Metal ion binding to humic substances: application of the non-ideal competitive adsorption model. Environ Sci Technol 29, 446-457.

Brookins, D.G., 1988. Use of sequential extraction to evaluate the heavy metals in mining wastes. Water Air Soil Pollut 50, 241-254.

Brooks, R.R., 1983. Biological Methods of Prospecting for Minerals. John Wiley \& Sons, New York. pp 322.

Clevenger, T.E., Saiwan, C., Koirtyoham, S.R., 1991. Lead speciation of particles on air filters collected in the vicinity of a lead smelter. Environ Sci Technol 25, 1128-1133.

Cuong, D.T., Obbard, J.P., 2006. Metal speciation in coastal marine sediments from Singapore using a modified BCR sequential extraction procedure. Applied Geochemistry 21, 1335-1346.

Davies, B.E., 1983b. Heavy Metal Contamination from Base Metal Mining and Smelting: Implications for Man and His Environment. In: Thornton I (ed) Applied Environmental Geochemistry. Academic Press, London, pp 425-462.

Dudka, S., Adriano, D.C., 1997. Environmental impacts of metal ore mining and processing: a review. J Environ Qual 26, 590-602.

Dudka, S., Chlopecka, A., 1990. Effect of solid-phase speciation on metal mobility and phytoavailability in sludge amended soil. Water Air Soil Pollut 51, 153-160.

Dutreuil, J.P., Bril, H., Roussel, C., Jarry, L., Petit, D., Minette, F., 1997. Grain size and mineralogical controls on vegetal colonisation of tailings in a former gold mine (La Petite Faye Massif central, France). In: Papunen H (ed) Mineral Deposits. Balkema, Rotterdam, pp: 895-898.

Elliott, H.A., Dempsey, B.A., Maille, M.J., 1990. Content and fractionation of heavy-metals in water treatment sludges. J Environ Qual 19, 330-334.

Ettler, V., Johan, Z., Kříbek, B., Šebek, O., Mihaljevič, M., 2009. Mineralogy and environmental stability of slags from the tsumeb smelter, Namibia. Appl Geochem $21,1-15$.

Fernándeza, E., Jiméneza, R., Lallenab, A.M., Aguilera, J., 2004. Evaluation of the BCR sequential extraction procedure applied for two unpolluted Spanish soils. Environmental Pollution 131, 355-364. 
Filippi, M., Golia, V., Pertold, Z., 2004. Arsenic in contaminated soils and anthropogenic deposits at the Mokrsko, Roundy, and Kasperske Hory gold deposits, Bohemiam Massif (CZ). Environ Geol 45, 716-730.

Ghosh, A.K., Sarkar, D., Nayak, D., Bhattacharyya, P., 2004. Assessment of a sequential extraction procedure for fractionation of soil arsenic in contaminated soils. Arch Agron Soil Scien 50, 583-591.

Hass, A., Fine, P., 2010. Sequential selective extraction procedures for the study of heavy metals in soils, sediments, and waste materials - a critical review. Critical Reviews in Environmental Science and Technology 40, 365-399.

Hongyu, L., Anne, P., Bohan, L., 2005. Metal contamination of soils and crops affected by the Chenzhou lead/zinc mine spill (Hunan, China). Science of the Total Environment $339,153-166$.

ISO (1999) Soil Quality. Guidance on the ecotoxicological characterization of soils and soil materials Guidelines no ISO TC 190/SC 7 ISO/DIS 15799. ISO Geneva Switzerland.

ISO norm 11466 (1995) Soil quality, extraction of trace elements soluble in aqua regia.

Kaasalainen, M., Yli-Halla, M., 2003. Use of sequential extraction to assess metal partitioning in soils. Environ Pollut 126, 225-233.

Kabala, C., Singh, B.R., 2001. Fractionation and mobility of copper, lead and zinc in soil profiles in the vicinity of a copper smelter. J Environ Qual 30, 485-492.

Kabata-Pendias, A., Pendias, H., 2001. Trace Elements in Soils and Plants. CRC Press LLC, Boca Raton, Florida, USA.

Kapusta, P., Szarek-Łukaszewska, G., Stefanowicz, A.M., 2011. Direct and indirect effects of metal contamination on soil biota in a $\mathrm{Zn}-\mathrm{Pb}$ post-mining and smelting area ( $\mathrm{S}$ Poland). Environ Pollut 159, 1516-22.

Kennedy, V.H., Sanchez, A.L., Oughton, D.H., Rowland, A.P., 1997. Use of single and sequential chemical extractants to assess radionuclide and heavy metals availability from soils for root up-take. Analyst 122, 89-100.

Kiekens, L., 1995. Zinc. In: Alloway BJ (ed) Heavy Metals in Soils. Blackie Academic and Professional, London, pp: $284-305$.

Krishnamurti, G.S.R., Huang, P.M., Van Rees, K.C.J., Kozak, L.M., Rostad, H.P.W., 1995. Speciation of particulate-bound Cadmium of soils and its bioavailability. Analyst 120, $659-665$.

Li, X., Thornton, I., 2001. Chemical partitioning of trace and major elements in soils contaminated by mining and smelting activities. Applied Geochemistry 16, 16931706. 
MacLaren, R.G., Crawford, D.V., 1973. Studies on soil copper. I. The fractionation of copper in soils. J Soil Sci 24, $172-181$.

Marin, B., Valladone, M., Polve, M., Monaco, A., 1997. Reproducibility testing of a sequential extraction scheme for the determination of trace metal speciation in a marine reference sediment by inductively coupled plasma-mass spectrometry. Analytica Chimica Acta 342, $91-112$.

Matera, V., Le Hecho, I., Laboudigue, A., Thomas, P., Tellier, S., Astruc, M., 2003. A methodological approach for the identification of arsenic bearing phases in polluted soils. Environ Pollut 126, 51- 64.

McGarth, S.P., Loveland, P.J., 1992. The Soil Geochemical Atlas of England and Wales. Blackie Academic and professional London.

Merian, E., Thomas, W., Clarkson, 1991. Metals and their compounds in the environment: occurrence, analysis, and biological relevance. VCH The University of Michigan.

Nabulo, G., Young, S.D., Black, C.R., 2010. Assessing risk to human health from tropical leafy vegetables grown on contaminated urban soils. Science of the Total Environment 408, 5338-5351.

Nannoni, F., Protano, G., Riccobono, F., 2011. Fractionation and geochemical mobility of heavy elements in soils of a mining area in Northern Kosovo. Geoderma 161, 63-73.

Narwal, R.P., Singh, B.R., Salbu, B., 1999. Association of cadmium, zinc, copper, and nickel with components in naturally heavy metal-rich soils studied by parallel and sequential extractions. Commun Soil Sci Plant Anal 30, 1209-1230.

Néel, C., Bril, H., Courtin-Nomade, A., Dutreuil, J-P., 2003. Factors affecting natural development of soil on 35-year-old sulphide-rich mine tailings. Geoderma 111, 1-20.

Nénert, S., Bril, H., Floc'h, J.P., 1997. Les districts aurifères du Haut-Limousin, Massif central français: approche minéralogique et géochimique. Chronique Recherche Minière 526, 3 - 15.

Nóvoa-Muñoz, J.C., Queijeiro, J.M., Blanco-Ward, D., Alvarez-Olleros, C., García-Rodeja, E., Martínez-Cortizas, A., 2007. Arsenic fractionation in agricultural acid soils from NW Spain using a sequential extraction procedure. Sci Total Environ 378, 18 - 22.

Nowak, B.,1995. Sequential extraction of metal forms in the soil near a roadway in southern Poland. Analyst 120, 737-739.

Pardo, R., Barrado, E., Prez, L., Vega, M., 1990. Determination and speciation of heavy metals in sediments of Pisuerga river. Water Res 24, 373-379. 
Paulo, J.C., Favas, J.P., Elisa, P., Gomes, V., 2011. Selective chemical extraction of heavy metals in tailings and soils contaminated by mining activity: Environmental implications. Journal of Geochemical Exploration 111, $160-171$.

Petit, M.D., Rucandio, M.I. 1999. Sequential extractions for determination of cadmium distribution in coal fly ash, soil and sediment samples. Analytica Chemica Acta 401, 283-291.

Pueyo, M., Mateu, J., Rigol, A., Vidal, M., Lopez-Sanchez, JF., Rauret, G., 2008. Use of the modified BCR three-step sequential extraction procedure for the study of trace element dynamics in contaminated soils. Environmental Pollution 152, 330-341.

Ramos, L., Hernandez, M., Gonzalez, M.J. 1994. Sequential fractionation of copper, lead, cadmium and zinc in soils from or near Donana National Park. J Environ Qual 23, 50 -57 .

Rauret, G., 1998. Extraction procedure for the determination of heavy metals in contaminated soil and sediment. Talanta 46, 449-455.

Rodriguez, L., Ruiz, E., Alonso-Azcaratec, J., Rincon, J., 2009. Heavy metal distribution and chemical speciation in tailings and soils around $\mathrm{a} \mathrm{Pb}-\mathrm{Zn}$ mine in Spain. Journal of Environmental Management 90, 1106 -1116.

Romaguera, F., Boluda, R., Fornes, F., Abad, M., 2008. Comparison of three sequential extraction procedures for trace element partitioning in three contaminated Mediterranean soils. Environmental Geochemistry and Health 30, 171-175.

Sahuquillo, A., Lopez-Sanchez, J.F., Rubio, R., 1999. Use of a certified reference material for extractable trace metals to assess sources of uncertainty in the BCR three stage sequential extraction procedures. Anal Chim Acta 382, 317-327.

Salbu, B., Krekling, T., Oughton, D.H., 1998. Characterization of radioactive particles in the environment. Analyst 123, 843-849.

Sanchez, G., Moyano, A., Munez, C., 1999. Forms of cadmium, lead, and zinc in polluted mining soils and uptake by plants (Soria Province, Spain). Commun Soil Sci Plant Anal 30, 1385-1402.

Schuwirth, N., Voegelin, A., Kretzschmar, R., Hofmann, T., 2007. Vertical distribution and speciation of trace metals in weathering flotation residues of a zinc/lead sulfide mine. $\mathrm{J}$ Environ Qual 36, 61-69.

Shu, W.S., Ye, Z.H., Lan, C.Y., Zhang, Z.Q., Wong, M.H., 2001. Acidification of lead/zinc mine tailings and its effect on heavy metal mobility. Environ Int 26, 389-394.

Shuman, L.M., 1985. Fractionation method for soil micro elements. Soil Sci 140, $11-22$. 
Stone, M., Marsalek, J., 1996. Trace metal composition and speciation in street sediment: Sault Ste. Marie, Canada. Water Air Soil Pollution 87, 149 - 169.

Storer, D.A., 1984. A simple high sample volume ashing procedure for determining soil organic matter. Commun Soil Sci Plant Anal 15, 759 - 772.

Sutherland, A., 2000. Comparison between non-residual Al, Co, Cu, Fe, Mn, Ni, Pb and Zn released by a three-step sequential extraction procedure and a dilute hydrochloric acid leach for soil and road deposited sediment. Applied Geochemistry 17, 353 - 365.

Szulczewski, M.D., Helmke, P.A., Bleam, W.F., 1997. Comparison of XANES analyses and extractions to determine chromium speciation in contaminated soils. Environ Sci Technol 31, 2954-2959.

Tessier, A., Campbell, P., Bosson, M., 1979. Sequential extraction procedure for speciation of particulate trace elements. Analyt Chemist 51, 844-851.

Thiry, M., van Oort, F., 1999. Les phases minérales majeures et mineures d'une friche industrielle de métallurgie des métaux non ferreux: état d'altération, évolution géochimique et devenir des métaux polluants du site de Mortagne-du-Nord, In: Les cahiers des clubs CRIN, acte du colloque 'La Spéciation des Métaux dans le Sol. Association ECRIN Paris pp. 108-159.

Tipping, E., Thompson, D.W., Ohnstad, M., Hetherington, N.B., 1986. Effects of pH on the release of metals from naturally-occurring oxides of Mn and Fe. Environ Technol Lett $7,109-114$.

Tokalioglu, S., Kartal, S., Elci, L., 2000. Determination of heavy metals and their speciation in lake sediments by flame atomic absorption spectrometry after a four-stage sequential extraction procedure. Anal Chim Acta 413, 33-40.

Tokalioglu, S., Kartal, S., Elci, L., 2000. Determination of heavy metals and their speciation in lake sediments by flame atomic absorption spectrometry after a four-stage sequential extraction procedure. Analytica Chimica Acta 413, 33-40.

Ure, A.M., Quevauviller, P.h., Muntau, H., Griepink, B., 1993. Speciation of heavy metal in soils and sediments. An account of the improvement and harmonisation of extraction techniques undertaken under the auspices of the BCR of the Commission of the European Communities. Int J Environ Anal Chem 51, 135 -151.

Ure, A.M., Davidson, C.M., 2001. Chemical Speciation in the Environment. Blackie, Glasgow, pp: 265-321.

Ure, A.M., Davidson, C.M., Thomas, R.P., 1995. Single and sequential extraction schemes For Trace metal speciation in soil and sediment.Tech and Instru in Anal Chem 17, 505-523. 
Vaněk, A., Borůvka, L., Drábek, O., Mihaljevič, M., Komárek, M., 2005. Mobility of lead, zinc and cadmium in alluvial soils heavily polluted by smelting industry. Plant Soil Environ 51, 316-21.

Weber, J.B. 1991a. Fate and behavior of herbicides in soil. Applied plant science 5, 28-41.

Wilson, S.C., Lockwood, P.V., Ashley, P.M., Tighe, M., 2010. The chemistry and behavior of antimony in the soil environment with comparisons to arsenic: A critical review. $\mathbf{J}$ Environ Pollut 158, 1169-81.

Žemberyová, M., Barteková, J., Hagarová, I., 2006. The utilization of modified BCR threestep sequential extraction procedure for the fractionation of $\mathrm{Cd}, \mathrm{Cr}, \mathrm{Cu}, \mathrm{Ni}, \mathrm{Pb}$ and $\mathrm{Zn}$ in soil reference materials of different origins. Talanta 70, 973-978. 